\title{
Hubungan Sifat Optik terhadap Kinerja Sel Surya DSSC Transparan Berbahan Dye Sintetik DN-F01 sebagai Sensitizer
}

\author{
Agus Supriyanto ${ }^{1 *}$, Ari Handono Ramelan ${ }^{1}$, Mohd Khairul Bin Ahmad ${ }^{2}$, \\ Febrina Ramadhani ${ }^{1}$, Diani Galih Saputri ${ }^{1}$ \\ ${ }^{1}$ Departemen Fisika FMIPA UNS, Surakarta \\ ${ }^{2}$ Department of Electronics Engineering, Universiti Tun Hussein Onn Malaysia \\ *agusf22@staff.uns.ac.id
}

\begin{abstract}
Dye sensitized solar cell (DSSC) is the third generation of solar cells that currently developing by researchers to get the best performance. The selection of dye as a component of DSSC has a big influence in the light absorption process. In this study, DN-F01 organic dye was used as a sensitizer with various concentrations. The optical properties test was carried out on the DN-F01 dye solution by UV-Vis spectrophotometer (Shimadzu UV-1800) and the DSSC fabricated performance was tested by portable solar simulator (ORIEL Sol1A). From the results, the DNF01 absorbance has ability to absorb light in the $300-500 \mathrm{~nm}$ wavelength range. The greatest efficiency value in this research is $2.44 \%$ obtained from the sample was immersed with the largest concentration of dye DN-F01 which has the smallest band gap energy of $2.38 \mathrm{eV}$.
\end{abstract}

Keywords: DSSC, DN-F01, absorbance, band gap

\section{ABSTRAK}

Dye sensitized solar cell (DSSC) merupakan generasi ketiga sel surya yang saat ini terus dikembangkan oleh para peneliti untuk mendapatkan kinerja terbaik. Salah satu langkah penting yang dilakukan adalah pemilihan dye sebagai salah satu komponen yang berpengaruh besar dalam proses penyerapan cahaya. Pada penelitian ini digunakan dye organik sintetik DN-F01 sebagai sensitizer dengan variasi konsentrasi. Pengujian sifat optik dilakukan pada larutan dye sintetik DN-F01 menggunakan spektrofotometer UV-Vis (Shimadzu UV-1800) dan uji kinerja sel surya yang telah difabrikasi menggunakan portable solar simulator (ORIEL Sol1A). Dari hasil pengujian diperoleh nilai serapan energi dye sintetik DN-F01 memiliki kemampuan serapan pada rentang panjang gelombang 300-500 nm. Nilai efisiensi terbesar pada penelian ini adalah $2,44 \%$ diperoleh dari sampel pada perendaman dye sintetik DN-F01 dengan konsentrasi terbesar yang memiliki celah pita energi terkecil sebesar 2,38 eV.

Kata kunci: DSSC, dye DN-F01, serapan energi, celah pita energi

\section{PENDAHULUAN}

Energi surya sebagai sumber energi terbarukan memiliki potensi yang cukup besar untuk memenuhi penggunan energi listrik. Pemanfaatan energi surya sebagai sumber energi listrik saat ini masih sangat kecil, untuk mengoptimalkannya para peneliti terus melakukan penelitian dan pengembangan terhadap teknologi perangkat sel surya salah satunya yaitu perangkat sel surya Dye Sensitized Solar Cell (DSSC) ${ }^{[1,2] \text {. }}$

DSSC merupakan perangkat sel surya generasi ketiga yang dikembangkan oleh O'Regan dan Grätzel yang memiliki beberapa keunggulan diantaranya fabrikasi yang mudah, ramah lingkungan, biaya yang murah, dan plastisitas yang baik ${ }^{[3-5]}$. Secara umum komponen 
penyusun DSSC terdiri dari substrat konduktif transparan, dye, semikonduktor, elektrolit dan elektroda lawan ${ }^{[6]}$. Prinsip kerja DSSC adalah perpaduan antara optik, listrik, dan kimia ${ }^{[7]}$, serta didasarkan pada sensitisasi lapisan semikonduktor celah pita energi melalui pewarna yang sesuai yang mampu menyerap cahaya tampak ${ }^{[8]}$.

Titanium dioksida $\left(\mathrm{TiO}_{2}\right)$ secara luas digunakan sebagai fotokatalisis dan elektroda dalam sel surya, dan telah dianggap sebagai bahan yang menjanjikan karena sifat fisik dan kimianya ${ }^{[9]}$. $\mathrm{TiO}_{2}$ sebagian besar juga digunakan sebagai pigmen dalam cat serta bahan pelapis dalam film tipis optik karena sangat transparan dan memiliki indeks bias tinggi dan daya tahan kimia di daerah IR dan cahaya tampak. $\mathrm{TiO}_{2}$ sangat menarik dalam aplikasi teknologi karena fase morfologi dan kristalinnya yang memiliki tiga fase kristalografi yang berbeda: brookite, anatase dan rutile. $\mathrm{TiO}_{2}$ memiliki sejumlah sifat yang menarik seperti celah pita lebar $(3,2 \mathrm{eV})$ untuk anatase, non toksisitas, transparansi dalam cahaya tampak, refraktivitas tinggi dan dielektrik konstan ${ }^{[10,11]}$.

Dye sebagai fotosensitizer memiliki fungsi utama dalam menyerap foton dan mengubah energi matahari menjadi listrik ${ }^{[12]}$. Semakin lebar jangkauan panjang gelombang yang dapat diserap oleh dye maka akan semakin banyak foton yang diserap sehingga dapat meningkatkan kinerja DSSC. Dye yang digunakan sebagai sensitizer harus memiliki kemampuan serapan pada rentang panjang gelombang tampak 400-800 nm, stabil, tidak mudah terdegradasi, dan mengikat kuat permukaan oksida semikonduktor ${ }^{[13]}$. Dye pada DSSC diklasifikasikan menjadi dye alami, organik dan logam-organik. Dye organik memiliki kelebihan yaitu koefisien extinction molar tinggi sehingga cocok diaplikasikan pada semikonduktor $\mathrm{TiO}_{2}{ }^{[14]}$. Pada penelitian ini digunakan dye organik sintetik dari Dyenamo Company tipe DN-F01 sebagai sensitizer yang merupakan pewarna organik gugus triphenylamine (TPA) dengan karakteristik unik seperti non planaritas dan koefisien serapan molar tinggi ${ }^{[15]}$.

Proses konversi energi dalam DSSC melibatkan zat warna yang menyerap foton (energi hv) dan elektron disuntikkan ke dalam pita konduksi $\mathrm{TiO}_{2}$. Elektron kemudian menuju elektroda melalui semikonduktor $\mathrm{TiO}_{2}$ yang menyebabkan pewarna teroksidasi kemudian diregenerasi oleh $\mathrm{I}^{-}$dalam elektrolit dan $\mathrm{I}^{-}$diregenerasi oleh reduksi $\mathrm{I}_{3}{ }^{-}$pada elektroda lawan ${ }^{[16]}$. Koneksi antara $\mathrm{TiO}_{2}$ pada elektroda kerja memainkan peran penting dalam mencapai efisiensi konversi cahaya tinggi ke listrik pada perangkat sel surya DSSC. Selain itu dibutuhkan fotogenerasi elektron yang mengalir ke film oksida dengan sedikit kerugian untuk rekombinasi antar permukaan sel sehingga menghasilkan efisiensi konversi yang tinggi ${ }^{[17]}$.

\section{METODE}

Pada penelitian ini digunakan Fluorine-doped Tin Oxide (FTO) sebagai substrat kaca konduktif, pasta $\mathrm{TiO}_{2}$ transparan 18-20 nm, dye organik sintetik tipe DN-F01 sebagai sensitizer yang diperoleh dari Dyenamo Company, dan pasta platina tipe DN-EP01 sebagai elektroda lawan. Deposisi lapisan semikonduktor $\mathrm{TiO}_{2}$ dan elektroda lawan platina pada FTO berukuran $(2 \times 2) \mathrm{cm}^{2}$ dengan area aktif $(0,7 \times 0,7) \mathrm{cm}^{2}$ menggunakan metode spin coating dengan kecepatan $1000 \mathrm{rpm}$. Sampel yang sudah dideposisi kemudian diannealing mengguakan furnace carbolite dengan suhu $450^{\circ}$ C. Dye sintetik DN-F01 dilarutkan menggunakan etanol dengan variasi konsentrasi larutan $2 \times 10^{-3} \mathrm{M}, 7 \times 10^{-3} \mathrm{M}$, dan $10 \times 10^{-3} \mathrm{M}$ dan diberi inisial masing-masing $\mathrm{Y}$ 1, Y2, dan Y3. Larutan kemudian distirrer dengan kecepatan $350 \mathrm{rpm}$ pada suhu $40^{\circ} \mathrm{C}$ selama 1 jam hingga homogen. 
Pada penelitian ini karakterisasi optik dilakukan pada larutan dye sintetik DN-F01 menggunakan spektrofotometer UV-Vis (Shimadzu UV-1800) untuk memperoleh nilai serapan energi dan celah pita energi. Kinerja sel surya DSSC yang telah difabrikasi diuji menggunakan portable solar simulator (ORIEL Sol1A).

\section{HASIL DAN PEMBAHASAN}

Inisial larutan dye Y1, Y2, dan Y3 diuji menggunakan spektrofotometer UV-Vis dengan rentang panjang gelombang 300-800 $\mathrm{nm}$. Hasil pengujian menunjukkan daya serapan energi pada setiap larutan terjadi pada rentang panjang gelombang 300-500 nm seperti yang terlihat pada Gambar 1. Nilai ini sesuai dengan hasil penelitian oleh Hagberg et al (2007) serta Tiwari dan Pal (2015) yang menunjukkan serapan energi larutan dye sintetik DN-F01 terjadi pada panjang gelombang 300-500 nm ${ }^{[18,15]}$. Dari Gambar 1. terlihat bahwa ketiga larutan memiliki bentuk grafik yang cenderung sama dengan nilai serapan energi yang berbeda. Perbedaan nilai serapan energi yang diperoleh dipengaruhi oleh besarnya konsentrasi setiap larutan. Serapan energi suatu senyawa pada suatu panjang gelombang tertentu bertambah dengan banyaknya molekul yang mengalami transisi yang nilainya bergantung pada struktur elektronik senyawa, kepekatan, dan panjang sel suatu material ${ }^{[19]}$.

Larutan Y3 dengan konsentrasi terbesar memiliki nilai serapan energi sebesar 3,95 a.u dengan dua puncak yaitu $407 \mathrm{~nm}$ dan $487 \mathrm{~nm}$ pada rentang sinar tampak dengan panjang gelombang 400-500 $\mathrm{nm}$ serta serapan energi sebesar 4,10 a.u dengan puncak gelombang $313 \mathrm{~nm}$ untuk serapan pada sinar ultraviolet pada panjang gelombang 300-400 nm. Larutan Y2 memiliki nilai serapan energi 3,89 a.u dengan puncak gelombang $408 \mathrm{~nm}$ dan serapan energi 3,63 a.u dengan puncak gelombang $479 \mathrm{~nm}$ untuk serapan pada sinar tampak dengan panjang gelombang 400-500 nm serta serapan energi 4 a.u dengan puncak gelombang $313 \mathrm{~nm}$ untuk serapan sinar ultraviolet dengan panjang gelombang 300-400 nm. Larutan Y1 memiliki nilai serapan energi 3,85 a.u dengan puncak gelombang $409 \mathrm{~nm}$ dan serapan energi 3,48 a.u dengan puncak gelombang $465 \mathrm{~nm}$ untuk serapan pada sinar tampak dengan panjang gelombang 400-500 nm serta serapan energi 2,97 a.u dengan puncak gelombang $310 \mathrm{~nm}$ untuk serapan sinar ultraviolet dengan panjang gelombang $300-400 \mathrm{~nm}$.

Sinar ultraviolet pada rentang panjang gelombang 200-400 $\mathrm{nm}$ dan sinar tampak pada rentang panjang gelombang 400-800 nm, memiliki energi yang cukup untuk membuat elektron pada kulit terluar berpindah ke tingkat energi yang lebih tinggi ${ }^{[20]}$. Hasil pengukuran spektrum serapan energi yang disajikan pada Gambar 1. mengindikasikan bahwa dye sintetik DN-F01 dengan kemampuan penyerapan energi pada rentang panjang gelombang 300-500 nm mampu mengeksitasi eksiton (electron-hole) dari Highest Occupied Molecular Orbital (HOMO) menuju Lowest Unoccupied Molecular Orbital (LUMO). Penyerapan pada panjang gelombang sinar tampak terjadi karena transisi transfer muatan intra-molekul dalam dye, dan dasar untuk transisi ini adalah adanya efek dorong-tarik molekul elektronik. Donor elektron dan akseptor dalam D- $\pi-\mathrm{A} d y e$ bertindak sebagai sistem elektron dorong-tarik; semakin kuat efek dorong-tarik elektron, semakin jelas efek transfer muatan intra-molekul dan semakin banyak pita serapan pada daerah panjang gelombang yang lebih besar ${ }^{[21]}$. Hal ini memungkinkan semakin banyak foton yang dapat diserap oleh $d y e$ untuk dikonversi menjadi energi listrik.

Sistem yang bertanggung jawab terhadap serapan cahaya disebut dengan kromofor. Kromofor yang menyebabkan eksitasi dari $\sigma$ (orbital bonding) ke $\sigma^{*}$ (orbital unbonding) adalah sistem yang mempunyai elektron $\sigma$ pada orbital molekul ${ }^{[20]}$. Ketika molekul dye 
terpapar cahaya dengan panjang gelombang dan energi yang setara dengan perbedaan energi HOMO-LUMO, panjang gelombang ini akan menyerap energi yang dapat melerpaskan elektron dari HOMO ke LUMO ( $\sigma$ ke $\left.\sigma^{*}\right)$. Dye organik memiliki ikatan rangkap terkonjugasi dimana serapan optik dan transport muatan didominasi oleh sebagian orbit terdelokasi $\pi$ dan $\pi^{*}$. Kemampuan penyerapan dye pada panjang gelombang sinar tampak terjadi akibat transisi elektron dari $\pi-\pi^{*}$ yang nilai celah energinya lebih kecil daripada celah energi $\sigma-\sigma^{*}$. Eksitasi elektronik terendah dari molekul terkonjugasi adalah transisi $\pi-\pi^{*}$ dalam celah energi akibat penyerapan atau pengemisian energi cahaya dalam spektral tampak seperti ditunjukkan dalam Gambar 2. ${ }^{[22]}$

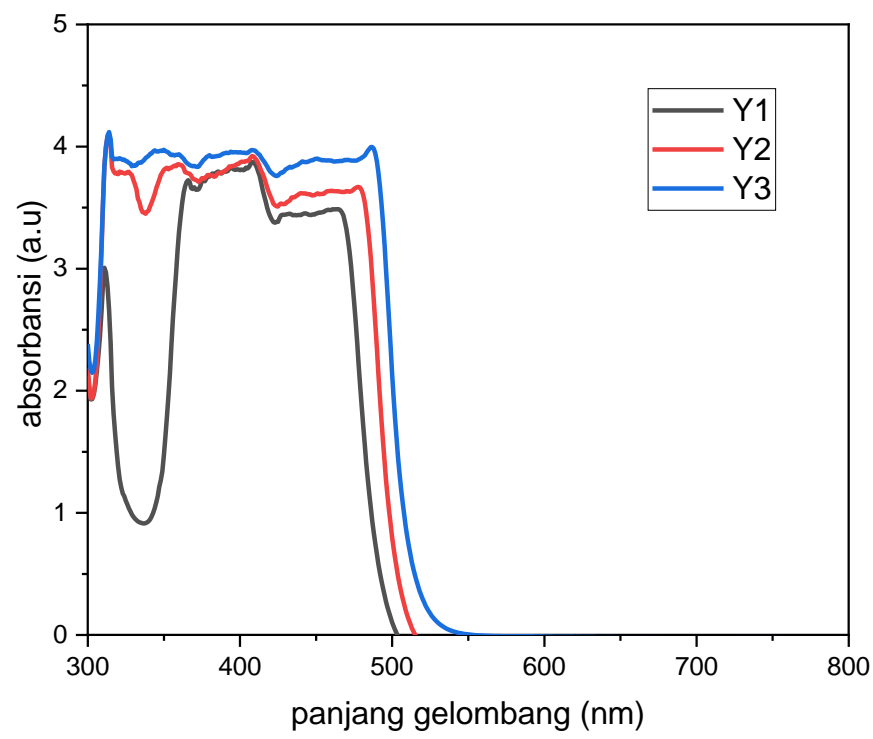

Gambar 1. Grafik serapan energi dye DN-F01

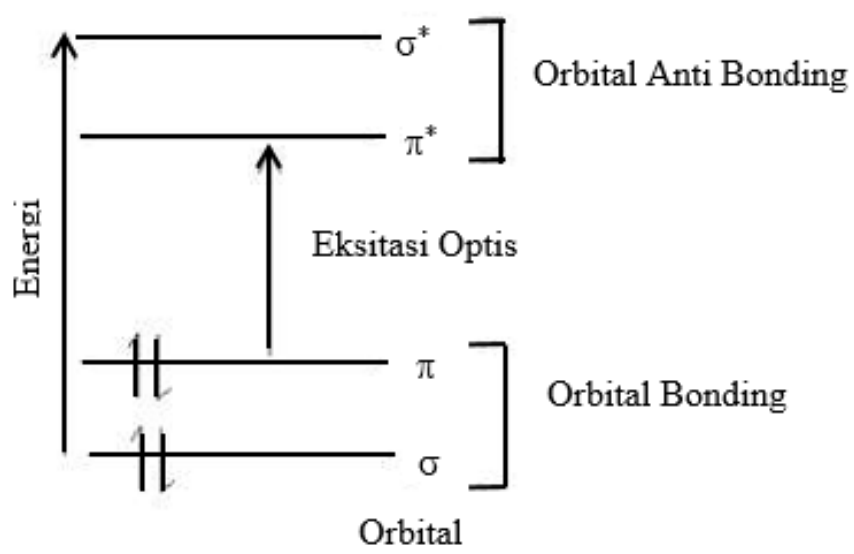

Gambar 2. Skema transisi elektronik dari orbital bonding ke tingkat orbital unbonding 


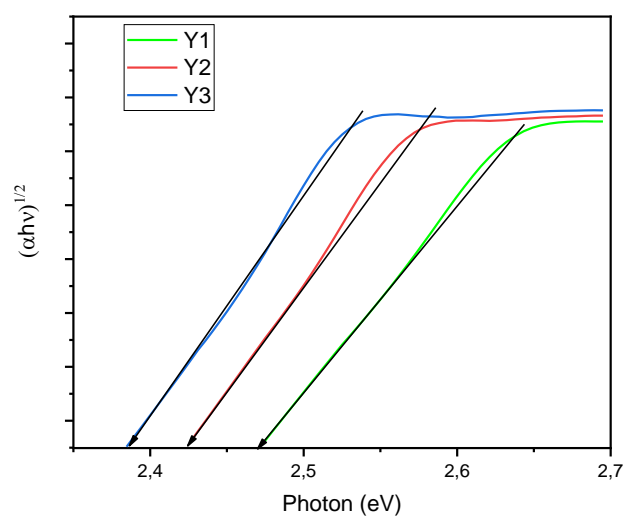

(a)

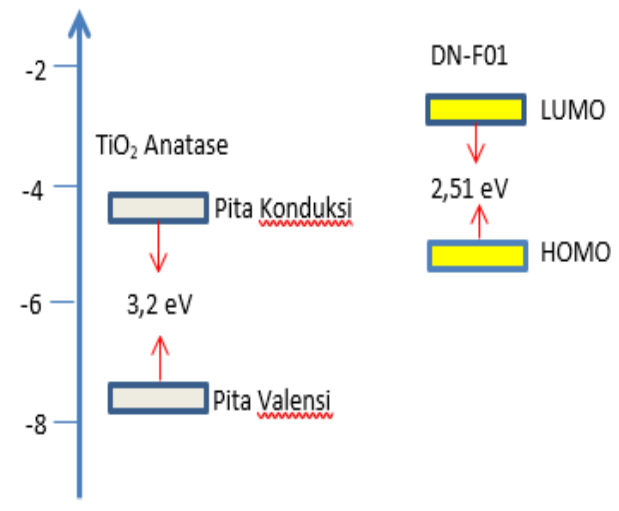

(b)

Gambar 3. (a) Celah energi larutan dye Y1, Y2, Y3; (b) Skema diagram energi TiO2 and DN-F01 ${ }^{[15]}$

Besarnya energi yang dibutuhkan untuk mengeksitasi elektron adalah sebesar celah pita energi antara pita valensi dan pita konduksi. Ketika photoanode berbasis semikonduktor sebagai elektroda kerja disinari oleh foton dengan energi lebih tinggi dari celah pita energi, elektron dalam pita valensi akan tereksitasi ke pita konduksi dan kemudian ke elektroda lawan untuk reaksi reduktif, sedangkan lubang yang tersisa di pita valensi akan mengambil bagian dalam reaksi oksidatif ${ }^{[23]}$.

Gambar 3(a) menunjukkan besarnya celah pita energi pada larutan dye Y1, Y2, dan Y3. Celah pita energi yang diperoleh untuk masing-masing larutan dye adalah 2, $47 \mathrm{eV} ; 2,42$ $\mathrm{eV}$; dan 2,38 eV. Adapun penelitian oleh Tiwari dan Pal (2015) diperoleh besar celah pita energi untuk dye sintetik DN-F01 adalah 2,51 eV yang nilainya lebih besar daripada larutan dye $\mathrm{Y} 1$, Y2, dan $\mathrm{Y}^{[15]}$. Celah pita energi larutan dye yang lebih kecil akan mempermudah proses generated electron pada tingkat energi ground state ke tingkat energi excited state sehingga akan mempermudah transfer elektron ke material lain pada struktur sel surya DSSC.

Tabel 1. I-V Kinerja DSSC

\begin{tabular}{ccccccc}
\hline Sampel & $\begin{array}{c}\boldsymbol{I S c} \boldsymbol{x} \\
\boldsymbol{1 0}^{-\mathbf{3}}(\boldsymbol{A})\end{array}$ & $\begin{array}{c}\boldsymbol{J} \boldsymbol{S c} \\
\left(\boldsymbol{m A} \boldsymbol{c m}^{\mathbf{2}}\right)\end{array}$ & $\begin{array}{c}\text { Voc } \\
(\text { volt })\end{array}$ & $\begin{array}{c}\text { Vmax } \\
(\text { volt })\end{array}$ & $\begin{array}{c}\text { Imax } \boldsymbol{x} \\
\mathbf{1 0}^{-3}(\boldsymbol{A})\end{array}$ & $\begin{array}{c}\text { Efisiensi } \\
(\boldsymbol{\%})\end{array}$ \\
\hline $\mathrm{Y} 1$ & 1,52 & 3,07 & 0,75 & 0,55 & 1,14 & 1,26 \\
$\mathrm{Y} 2$ & 2,17 & 4,40 & 0,78 & 0,55 & 1,54 & 1,75 \\
$\mathrm{Y} 3$ & 2,68 & 5,43 & 0,85 & 0,55 & 2,16 & 2,44 \\
\hline
\end{tabular}

Tabel 1. menyajikan kinerja sel surya DSSC dengan variasi konsentrasi larutan dye. Sel surya yang telah difabrikasi diuji menggunakan portable solar simulator. Dari hasil pengujian diperoleh efisiensi untuk setiap sampel Y1, Y2, dan Y3 masing-masing sebesar $1,26 \% ; 1,75 \%$; dan 2,44\%. Nilai ini menunjukkan bahwa semakin besar konsentrasi larutan dye yang digunakan sebagai sensitizer, maka efisiensi yang diperoleh akan semakin besar. Konsentrasi larutan dye yang besar akan menghasilkan celah pita energi yang kecil yang menyebabkan kemampuan serapan dan konduktivitas listrik menjadi lebih besar yang dapat meningkatkan kinerja dari sel surya DSSC dalam mengubah energi surya menjadi energi listrik. 


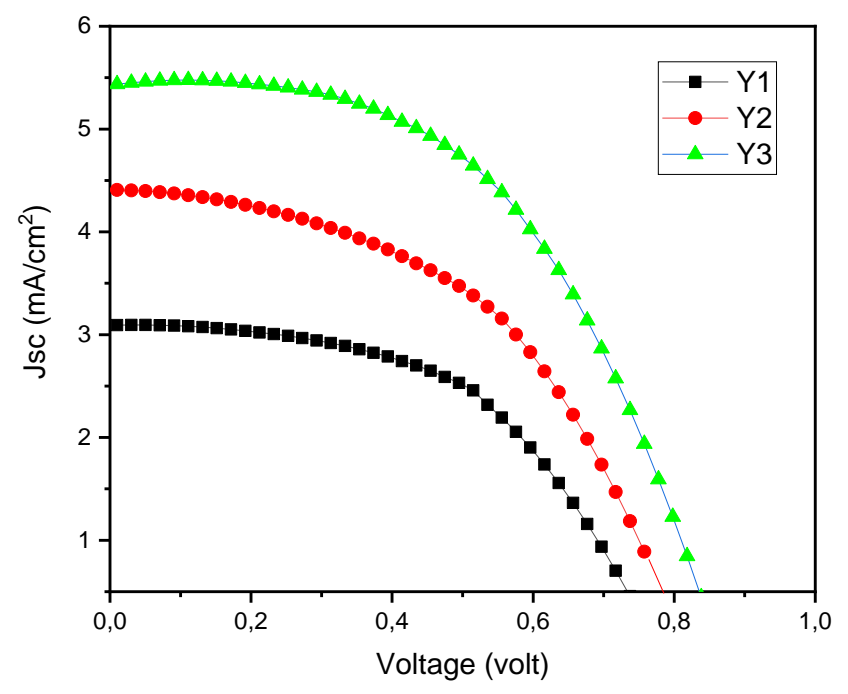

Gambar 4. Kurva I-V

Salah satu aspek yang mempengaruhi kinerja DSSC adalah jumlah molekul dye yang dapat diserap oleh lapisan $\mathrm{TiO}_{2}$. Semakin banyak molekul dye yang diubah untuk diadsorpsi maka penyerapan foton akan menjadi lebih besar dan menghasilkan nilai efisiensi yang lebih tinggi. Jumlah molekul dye yang diadsorpsi pada lapisan $\mathrm{TiO}_{2}$ dipengaruhi oleh molaritas larutan dye yang diserap ketika lapisan $\mathrm{TiO}_{2}$ dicelupkan dalam larutan dye ${ }^{[24]}$.

\section{KESIMPULAN}

Sifat optik larutan dye sebagai sensitizer akan mempengaruhi kinerja kinerja dari sel surya DSSC. Konsentrasi larutan $d y e$ yang besar menyebabkan kemampuan penyerapan cahaya oleh dye juga semakin besar. Semakin besar daya serapan, semakin kecil celah pita energi yang akan mempermudah proses generated electron pada tingkat energi ground state ke tingkat energi excited state sehingga akan mempermudah transfer elektron ke material lain pada struktur sel surya DSSC.

\section{ACKNOWLEDGEMENT}

Penelitian ini didanai oleh Hibah Penelitian Unggulan Perguruan Tinggi 2020 pada PNPB UNS (HGR-UNS), nomor kontrak 452/UN27.21/PN/2020, Universitas Sebelas Maret Indonesia dan didukung oleh laboratorium MINT-SRC, Universitas Tun Hussein Onn Malaysia.

\section{DAFTAR PUSTAKA}

1 Bomben, P.G., Robson, K.C.D., Koivisto, B.D., \& Berlinguette, C.P. 2012. Cyclometalated Ruthenium Chromophores for the Dye-Sensitized Solar Cell. Coordinate Chemistry Reviews, pp. 1438-1450.

2 Ahmad, M.S., Pandey, A.K., \& Rahim, N.A. 2017. Advacements in the Development of $\mathrm{TiO}_{2}$ Photoanodes and Its Fabrication Methods for dye Sensitized Solar Cell (DSSC) Applications. Renewable and Sustainable Energy Reviews, vo.77, pp.89-108.

3 Wu, K., Ma, J., Cui, W., Ruan, B., \& Wu, M. 2017. The Impact of Metal Ion Doping on the Performance of Flexible Poly (3,4-ethylenedioxythiophene) (PEDOT) Cathode 
in Dye-Sensitized Solar Cells. Journals of Photochemistry and Photobiology A: Chemistry, pp. 29-34.

4 Yang, C., Zhang, H.Q., Zheng, \& Y.R. 2011. DSSC with novel Pt Counter Electrodes Using Pulsed Electroplating Techniques. Current Applied Physics, vol. 11, pp. S147S153.

5 Wan, Z., Zhou, L., Jia, C., Chen, X., Li, Z., Yao, \& X. 2014. Comparative Study on Photovoltaic Properties of Imidazole-Based Dyes Containing Varying Electron Acceptors in Dye-Sensitized Solar Cells. Synthetic Metals, vol.196, pp. 193-198.

6 Gong, J., Sumathya, K., Qiao, Q., \& Zhou, Z. 2017. Review on Dye-Sensitized Solar Cells (DSSCs): Advanced Techniques and Research Trends. Renewable and Sustainable Energy Reviews, vol. 68, hlm. 234- 246.

7 Sashank, T., Manikanta, B., \& Pasula, A. 2017. Fabrication and Experimental Investigation on Dye Sensitized Solar Cells Using Titanium Dioxide Nano Particles. Materials Today: Proceedings, 4, 3918-3925.

8 Zani, L., Dagar, J., Lai, S., Centi, S., Ratto, F., Pini, R., Calamante, M., Mordini, A., Reginato, G., \& Mazzoni, M. 2017. Studies on the Efficiency Enhancement of Cosensitized, transparent DSSCs by Employment of Core-shell-shell Gold Nanorods. Inorganica Chimica Acta, vol.470, pp. 407-415.

9 Grätzel, M. 2005. Solar Energy Conversion by Dye-Sensitized Photovoltaic Cells. Inorg. Chem, vol. 44, 6841-6851.

10 Salman, S.H., Shihab, A.A., \& Elttrayef, A.H. 2019. Studying The Effect of The Type of Substrate on The Structural ,Morphology and Optical Properties of $\mathrm{TiO}_{2}$ Thin Films Prepared by RF Magnetron Sputtering. Energy Procedia, vol. 157, pp. 199-207.

11 Manickam, K., Muthusamy, V., Manickam S., Senthil, T.S., Periyasamy, G., \& Shanmugam, S. 2019. Effect of Annealing Temperature on Structural, Morphological and Optical Properties of Nanocrystalline Tio 2 Thin Films Synthesized by Sol-Gel Dip Coating Method. Materials Today: Proceedings, vol.23, pp.68-72.

12 Sa'adah, U., Himmah, S.W., Suprayogi, T., Diantoro, M., Sujito, S., \& Nasikhudin, N. 2019. The Effect of Time Deposition of $\mathrm{PAN} / \mathrm{TiO}_{2}$ Electrospun on Photocurrent Performance of Dye-Sensitized Solar Cell. Materials Today: Proceedings, 13, 175180

13 Kotteswaran, S., Mohankumar, V., Pandian, M.S., \& Ramasamy, P. 2017. Effect of Dimethylaminophenyl and Thienyl Donor Groups on Zn-Porphyrin for Dye Sensitized Solar Cell (DSSC) Applications. Inorganica Chimica Acta, vol.467, hlm. 256-263.

14 Schmidt-Mende, L., Bach, U., Humphry-Baker, R., Horiuchi, T., Miura, H., Ito, S., Uchida, S., \& Gratzel, M. 2005. Organic Dye for Highly Efficient Solid-State DyeSensitized Solar Cells. Advanced Material, vol. 17(7), pp. 813-815.

15 Tiwari, A., \& Pal, U. 2015. Effect Of Donor-Donor-P-Acceptor Architecture of Triphenylamine-Based Organic Sensitizers Over $\mathrm{TiO}_{2}$ Photocatalysts for VisibleLight-Driven Hydrogen Production. International Journal of Hydrogen Energy, vol. 40, issue 30, hlm. 9069-9079.

16 Selvaraj, P., Baig, H., Mallick, T.K, \& Sundaram, S. 2018. Charge Transfer Mechanics in Transparent Dye-Sensitised Solar Cells Under Low Concentration. Materials Letters, 222, 78-81.

17 Yang, C.H., Chen, H.L., Chuang, Y.Y., Wu, C.G., Chen, C.P., Liao, S.H., \& Wuang, T.L. 2009. Characteristics of Triphenylamie-based Dyes with Multiple Acceptors in Application of Dye-Sensitized Solar Cells. Journal of Power Sources, 188, 627-634

18 Hagberg, D., Marinado, T., Karlsson, K., Nonomura, P., Boschloo, G., Brinck, T., Hagfeldt, A., \& Sun, L. 2007. Tuning the HOMO and LUMO Energy Levels of 
Organic Chromophores for Dye Sensitized Solar Cells. Journal Organic Chemistry, vol. 72, pp. 9950-9956.

19 Fessenden, R., \& Fessenden, J. 1999. Kimia Organik. Jakarta: Erlangga.

20 Dachriyanus. 2004. Analisis Struktur Senyawa Organik Secara Spektroskopi. Lembaga Pengembangan Teknologi Informasi dan Komunikasi (LPTIK) Universitas Andalas

21 Zhang, H., Iqbal, Z., Chen, Z.E., \& Hong, Y.P. 2017. Effect of Structural Optimization on the Photovoltaic Performance of dithieno[3,2-b:2',3'- $d$ ]pyrrole-based DyeSensitized Solar Cells. Royal Society of Chemistry Advances, 7:, 35598-35607.

22 Brütting, W. 2005. Physics of Organic Semiconductors. Germany: WILEY-VCH Verlag GmbH \& Co. KGaA, Weinheim.

23 Shen, S., Chen, J., Wang, M., Sheng, X., Chen, X., Feng, X., \& Mao, SS. 2018. Titanium Dioxide Nanostructures for Photoelectrochemical Applications. Progress in Materials Science, 98, 299-385.

24 Setyawati, H., Darmoekoesoemo, H., Ningtyasa, A.T.A., Kadmib, Y., Elmsellemf, H., \& Kusumag, H.S. 2017. Effect of metal ion Fe(III) on the Performance of chlorophyll as photosensitizers on dye sensitized solar cell. Results in Physics, 7, 2907-2918. 